\title{
Nataša Gajšt
}

University of Maribor

Slovenia

\section{Business English as a Lingua Franca - A Cross-Cultural Perspective of Teaching English for Business Purposes}

\author{
Summary
}

In our era of globalisation, English is at the top of the languages used in international business. A vast majority of business communication in English is carried out by non-native speakers of English. In a cross-cultural exchange of information, the sender and the recipient come from different cultural backgrounds. The patterns of communication vary across the globe and non-native speakers tend to apply their native language patterns when communicating in English. This paper thus focuses on the concept of spoken communication and dimensions of culture and how they are reflected in communication patterns in different business situations. It also addresses the teaching of Business English as a lingua franca and the role of Business English teachers in helping learners develop their communicative and intercultural competence in order to communicate effectively in a multicultural work environment.

Key words: Business English, lingua franca, cross-cultural communication, communication patterns, Common European Framework of Reference for Languages (CEFR), communicative competence, intercultural competence

\section{Poslovna angleščina kot lingua franca - medkulturni vidik poučevanja poslovne angleščine}

\section{Povzetek}

Angleški jezik je v današnjem času globalizacije eden izmed najbolj razširjenih jezikov v poslovnem svetu. Velika večina poslovne komunikacije v angleškem jeziku poteka med nematernimi govorci tega jezika. Pri medkulturni izmenjavi informacij pošiljatelj in prejemnik sporočila prihajata iz različnih kultur. Načini komunikacije se med državami razlikujejo in nematerni govorci angleškega pogosto prenašajo jezikovne vzorce lastnih maternih jezikov v komunikacijo v angleščini. Pričujoči prispevek obravnava koncept govorjene komunikacije in dimenzije kulture ter ugotavlja, kako so te dimenzije izražene v komunikacijskih vzorcih v različnih poslovnih situacijah. Prispevek prav tako obravnava poučevanje poslovne angleščine kot lingua franca in vlogo učiteljev poslovne angleščine pri razvijanju komunikativne in medkulturne kompetence študentov kot dveh dejavnikov učinkovite komunikacije $\mathrm{v}$ večkulturnem poslovnem okolju.

Ključne besede: poslovna angleščina, lingua franca, medkulturna komunikacija, komunikacijski vzorci, Skupni evropski jezikovni okvir (SEJO), komunikativna kompetenca, medkulturna kompetenca 


\section{Business English as a Lingua Franca - A Cross-Cultural Perspective of Teaching English for Business Purposes}

\section{Introduction}

In the past decades, the expansion of economic globalisation has brought about an increase in international business co-operation and in the number of cross-border business partnerships. This, in turn, has resulted in the increasing number of contacts between business people from various cultural and linguistic backgrounds, as more and more people deal with foreigners either in their own communities or when travelling abroad. It is a well established fact that today English is one of the most frequently used languages in international communication. Apart from the communication between native speakers of English and non-native speakers of English, English is also the main language of communication between those who learn it as a foreign language. According to Sharifian and Jamarani $(2013,4)$, as much as $80 \%$ of communication around the world that takes place in English is carried out between non-native speakers of English. To illustrate, in 2004 about $74 \%$ of all communication in international tourism was between non-English speaking individuals and nonEnglish speaking individuals, which "demonstrates the scale of need for face-to-face international communication and a growing role for global English" (Graddol 2006, 29). English has thus in a way become de-nationalised as it is no longer exclusive to the countries where it is used as the native language, which clearly gives its use a multicultural dimension (McKay 2002).

As business co-operation is more and more global, the knowledge of cultural norms and communication styles of individual countries has become one of the key factors influencing business success. Since English plays a major role in the communication between business people from different nations and cultures, the main objectives of this paper are to address the dimensions of culture in communication, to highlight the differences in communication patterns of individual nations and to relate them to the use of English in international business settings. These issues serve as a framework for the discussion of BELF, i.e. Business English as a lingua franca, and its impact on the teaching of English for Business Purposes. Here, the focus is mainly on the communicative language competences and intercultural competence (i.e. the ability to successfully communicate with people from other cultures) as integral parts of Business English courses.

\section{Dimensions of culture and business communication in an intercultural context}

Apart from specialised business knowledge, success in international business strongly depends on the knowledge of cultural norms of individual countries, which are also reflected in the way people communicate. As business co-operation becomes increasingly culturally diverse, the need for understanding how ideas are expressed in individual cultures arises. According to Gudykunst and Lee $(2003$, 8-9) "[c]ommunication is unique within each culture and, at the same time, there are systematic similarities and differences across cultures". Tannen $(1984,189)$ similarly claims that the aspects of communication vary from culture to culture and asserts that the "ways of speaking are not extra-linguistic nor even paralinguistic but are the essence of language". Focusing on the way members of individual cultures communicate, Hall and Hall (1990), for example, distinguish between highcontext and low-context cultures, depending on the amount of linguistic context that is required for 
understanding a message. In high-context cultures (e.g. Japan, Arab countries, Greece, Spain), speakers rely on implicit communication and an indirect style of writing and speaking. On the other hand, in low-context cultures (e.g. Anglo-Saxon countries, German-speaking countries and Scandinavian countries) the emphasis is on explicit communication and a direct style in writing and speaking.

According to the principle of linguistic relativity (often referred to as the Sapir-Whorf hypothesis), the structure of language affects human thought processes and the way in which humans conceptualise reality. This view is also shared by Richard D. Lewis (2006), who focuses on cultures and their communication patterns primarily in business contexts. In his book on conducting business across cultures, When Cultures Collide: Leading Across Cultures, Lewis writes: "Whatever the culture, there's a tongue in our head" (Lewis 2006, 63). Lewis sees thought as internalised language and claims that nationals of different countries use their language and speech in different ways since different languages express different patterns of our thinking and of our behaviour. One of his key claims is that patterns of communication vary across the globe and that non-native speakers tend to apply the patterns of their native language when communicating in English (Lewis 2006, 11). The fact that different cultures have their specific ways of speaking and listening is important for raising the awareness of potential misunderstandings in communication. In order to be successful in business, one must be able to communicate their ideas well and one should be aware of how to communicate proposals and ideas to business partners from different cultures since, in the words of Rogerson-Revell $(2010,443)$, "[w] $[\mathrm{wile}$ people may well need to 'speak the same language' in [...] multilingual contexts, they may not necessarily 'speak the same way', for instance, because of underlying differences in sociocultural conventions or differences in linguistic competence."

Based on his extensive research into different cultures and their communication patterns, Lewis (2006) distinguishes between three cultural types, i.e. the linear-active cultures (e.g. Germany, the USA, Austria, the Czech Republic, Slovenia, Norway, the UK, the Netherlands), the multi-active cultures (e.g. Italy, Portugal, Spain, Greece, Argentina, Mexico, Brazil, Chile) and the reactive cultures (e.g. Japan, China, Vietnam, Korea, Thailand, Malaysia). According to Lewis (2006), individuals from linear-active cultures are considered to be polite but direct in their speech, talk half the time, confront with logic and use many facts, dislike losing face and have limited body language. On the other hand, people from multi-active nations are defined as those who talk most of the time, are emotional and also confront emotionally, often interrupt and display their feelings freely. The third group, i.e. the reactive nations, listen most of the time and are considered to be polite and indirect; they tend to hide their feelings and are keen on not losing face. They also conceal feelings and in general do not interrupt. Of course, these generalisations should be considered as guidelines only as one should be careful not reduce all "the members of a certain national group to pre-defined characteristics of a cultural label” (Holliday et al. 2010, 26).

Communication in business-related situations is directed towards the achievement of business objectives, which in the plainest of terms means reaching agreements, making deals. Apart from being used in written communication for business purposes (e.g. various types of business and commercial correspondence, business reports, proposals, etc.), English is also used in spoken interactions with business partners and clients mainly in the form of meetings, negotiations, presentations as well as socialising. Since the aim of these interactions is to achieve the common goal, i.e. to conduct business, it is very important for business people to present their ideas in such a way that they will be understood by their interlocutors.

Business presentations, for example, serve to introduce a certain product or service, or to provide information to potential clients or business partners. As a discourse, they are relatively structured, 
with the speaker presenting the contents and the audience listening. However, as has been established, cultures differ also in their listening habits and expectations as regards the general structure of business presentations. Again we turn to Lewis $(1999,54-7)$ for some examples of different listening habits around the globe. For instance, Americans would appreciate a lot of humour, joking and a hard sell; Germans and Dutch dislike jokes in business. Japanese and Finns prefer quiet and modest presentations with a lot of politeness and respect. In Arab countries, for instance, rhetoric, eloquence, liveliness and respect are expected, and in India, people are used to patience, sympathy, humility and 'flowery speech'.

The patterns of spoken communication are even more obvious in meetings, negotiations and even during small talk (including socialising). In meetings and negotiations, the participants are given a chance to communicate with their interlocutors and use their speaking skills to achieve the set objectives. For example, UK business people use humour, understatement, vagueness and a lot of small talk, whereas Americans speak clearly and directly, and they 'put their cards on the table immediately' with the sole purpose of doing business as soon as possible (Lewis 1999, 7). While the people from Finland "say only that which is absolutely necessary" and when something is considered unclear by their counterparts, they "repeat it in summarised form" (Lewis 1999, 14), the Italians "deliver their proposals at length" (Lewis 1999, 14) and in case of miscomprehension "may launch into a half an hour clarification of the original proposal" (Lewis 1999, 14). Although these generalisations could be considered stereotypical, they point out a very important fact: people do speak and behave differently across the world. If individuals from other cultures are not aware of these differences, this can cause misunderstandings, which, in turn, may lead to a loss of business. Nevertheless, we should not "allow the notion of 'culture' [and generalizations about different cultures] to become greater than the people themselves" (Holliday et al. 2010, 26).

\section{International business communication in English and Business English as a lingua franca}

In recent years, the research into business-related communication of non-native speakers of English in the English language has resulted in the emergence of the concept of BELF, i.e. Business English as a lingua franca. While some studies deal with BELF in general (e.g. Kankaanranta and Planken 2010, Gerritsen and Nickerson 2009), others look at specific instances of the use of BELF in a variety of professional contexts. For example, Wolfartsberger (2009) investigates the practices of the use of BELF in international meetings, and Ehrenreich (2010) presents a case of the use of English in a familyowned German multinational company. Also, Randén (2011) studies the use of BELF by Swedish professionals working in the pharmaceutical sector, while Louhiala-Salminen and Kankaanranta (2012) study English as business lingua franca as the context-specific resource for international internal communication. In addition, Rogerson-Revell (2010) is interested in the language adjustments that native speakers and non-native speakers of English make for an international audience in business meetings while Pullin (2010) researches small talk in English in international business situations. There is also the need to define the contents of Business English courses in view of the increasing international use of English in business contexts. Jung (2009), for instance, discusses pedagogical implications of teaching BELF in view of its communicative purpose in business contexts.

What kind of language is, then, Business English as a lingua franca? If English as a lingua franca is used in communication between speakers with different first languages (Seidlhofer 2005, 229), then Business English as a lingua franca is English used as the language of communication between business professionals whose first language is not English. It can thus be claimed that BELF is a variety of English used mostly in international business for conducting business between individuals and 
companies from various parts of the world. In the words of Louhiala-Salminen et al. (2005, 403-4), Business English as a lingua franca refers to English used as a neutral and shared communication code. It is neutral in the sense that none of the speakers can claim it as her/his mother tongue; it is shared in the sense that it is used for conducting business within the global business discourse community whose members are BELF users and communicators in their own right - not non-native speakers or learners. Business English as a lingua franca is thus a variety English that is used by nonnative speakers of English in which the characteristics of the speaker's mother tongue communication patterns are present. Further, it is considered to be simple and clear English (and is far from simplified English like Globish) which includes neither idiomatic expressions nor complicated phraseology. The sentence structures tend to be simple and its users make frequent grammatical mistakes. The most prominent feature of BELF, however, is business-related vocabulary and technical jargon. In short, Business English as a lingua franca is seen as a tool for communicating information with accuracy and clarity. And in business, this is undoubtedly related to 'getting the job done', which is the purpose of business in its most basic sense.

\section{Impact of BELF on teaching of English for Business Purposes}

All the issues presented above have an effect on Business English courses as the specific position of English as the main language in international business communication presents a challenge for the teachers of Business English. Our discussion so far thus gives rise to questions referring mainly to the contents of Business English courses the teachers are to deliver. What kind of Business English are we to teach? According to Smith (cited in McKay 2002, 12):

(a) learners of an international language do not need to internalize the cultural norms of native speakers of that language,

(b) the ownership of an international language becomes 'de-nationalized', and

(c) the educational goal of learning it is to enable learners to communicate their ideas and culture to others.

Focusing on the use of English in an international context, Sharifian $(2009,2)$ emphasises that it does not stand for any particular variety but is "a language of international, and therefore multicultural, communication".

Although the statements made by Smith (cited in McKay 2002) and Sharifian (2009) refer to the international use of a language in general, parallels can be drawn with the concept of Business English as a lingua franca. Namely, since the majority of its users are non-native speakers of English who are most likely to communicate with other non-native speakers of English, the need for the internationalization of native speakers' cultural norms becomes to a large degree unnecessary. We can also agree that the focus regarding the use of English in international business is on enabling the business people to communicate their business ideas to their business partners from other cultures.

Since language is embedded in the culture(s) in which it is used, the importance of cultural awareness in international business has become an important issue in Business English courses, due to the need of 'non-native English language' business people to communicate with other (both native and non-native) speakers of English for Business Purposes. Recently, there has been a lot of discussion on this topic among Business English practitioners who teach Business English to pre-experience 
students as well job-experienced learners (e.g. IATEFL BESIG ${ }^{1}$ Annual conference in Dubrovnik 2011, IATEFL BESIG Pre-Conference event at IATEFL Glasgow 2012). The requirements of both groups of learners are not only for grammar and vocabulary (i.e. linguistic knowledge of English), but also for being able to understand how people from other cultures communicate.

The challenges that Business English practitioners face are hence twofold. On the one hand, there is still the necessity to enhance the linguistic knowledge of the learners, while on the other hand the teachers are required to provide the learners with intercultural knowledge, more specifically, the knowledge of cross-cultural communication. That is, Business English teachers are expected to prepare the students to communicate well in English in a multicultural business environment.

\subsection{Linguistic knowledge and BE(LF)}

Let us address the question of linguistic knowledge first. Since English for Business Purposes is predominantly taught at tertiary level or to adult learners, and based on the fact that most learners of Business English have at least a core knowledge of general English vocabulary and grammar, the main emphasis, in our opinion, should be placed on specific business related terminology.

In the European context, the standards and levels of language knowledge are frequently identified and examined by referring to the Common European Framework of Reference for Languages (Council of Europe 2001, henceforth CEFR) scale descriptors. For the purpose of this paper, we have decided to focus on certain aspects of the communicative language competence as well as on the intercultural competence as defined in CEFR (since these two seem to be most relevant for the teaching of English for Business Purposes), and to relate them to the notion of Business English as a lingua franca.

\subsubsection{Communicative $\mathrm{BE}(\mathrm{LF})$ competence}

According to CEFR (Council of Europe 2001, 13), communicative language competence includes linguistic competences and sociolinguistic competences. Linguistic competences consist of lexical, grammatical, semantic, phonological, orthographic and orthoepic competences (Council of Europe 2001, 109). Although all these competences are important in language use, the focus in this paper will only be on lexical, grammatical and phonological competences as the core linguistic competences.

First, lexical competence of a language user is "the knowledge of, and the ability to use, the vocabulary of a language [and] consists of lexical elements and grammatical elements" (Council of Europe 2001, $110)$. If lexical competence in general means vocabulary range and vocabulary control, then it can be claimed that lexical $B E(L F)$ competence refers to business related terminology range and control. It is impossible to state exactly which level of lexical competence the speakers of $B E(L F)$ should be required to reach, for this question is related to the types of interactions they will have with their business counterparts. In general, however, the learners should be encouraged to master as extensive a general and specialised business-related terminology (e.g. marketing / accounting / financial terminology) as possible since words are key for communication. In our opinion, the minimum requirement for a competent speaker of English in business-related situations should be at least B2, i.e. they should have "a good range of vocabulary for matters connected to [their] field and most general topics" (Council of Europe 2001, 112).

BESIG stands for Business English Special Interest Group, which is a professional body within IATEFL. Its main interest is to bring together Business English practitioners all over the world to discuss issue related to teaching Business English. <http:// www.besig.org/events/default.aspx $>$ (accessed 17 August, 2012). 
Second, "[g] rammatical competence is the ability to understand and express meaning by producing and recognising well-formed phrases and sentences in accordance with these principles" (ibid., 113). The range and the types of grammatical categories should be closely related to the various business purposes and situations in which English is to be used. Similar to lexical competence, as high a grammatical accuracy as possible (although comprising simple grammatical structures only) without doubt contributes to effective communication.

The issue of the level of linguistic competence becomes more complicated as regards phonological competence. The concern arising in relation to this competence is mainly to which level the students are supposed to master an English phonological system. Is it enough to settle for the A2 CEFR level, which defines pronunciation as "generally clear enough to be understood despite a noticeable foreign accent" (Council of Europe 2001, 117), or the B1 level, which says that "pronunciation is clearly intelligible even if a foreign accent is sometimes evident and occasional mispronunciations occur" (Council of Europe 2001, 117), or should the norm be the C1 level, where the speaker "can vary intonation and place sentence stress correctly in order to express finer shades of meaning" (Council of Europe 2001, 117)? Also, considering different English accents, which variety is to be the norm, and should one aim for C1 level of proficiency? Since we know that most communication for business purposes takes place between non-native speakers of English, the need for achieving the C1 level does not seem to be very important.

\subsubsection{Sociolinguistic competence and $B E(L F)$}

Sociolinguistic competence, as "the knowledge and skills required to deal with the social dimension of language use" (Council of Europe 2001, 118), is closely related to sociocultural competence, i.e. to "the knowledge of the society and culture of the community or communities in which a language is spoken" (Council of Europe 2001, 102). It includes concepts such as the use and choice of greetings and different forms of addressing people (formal or informal), the conventions for turn-taking and politeness conventions, expressions of folk wisdom (e.g. idioms, proverbs, familiar quotations, etc.) as well as register differences and dialects and accents (Council of Europe 2001, 119-21). In view of the definition and purpose of Business English as a lingua franca, this area of language can be quite challenging to address in a $\mathrm{BE}(\mathrm{LF})$ course.

As mentioned, the speakers of $\mathrm{BE}(\mathrm{LF})$ tend to apply the norms of their native languages when communicating in English. The first concern regarding the above concepts is therefore what kind of greetings, address forms, forms of politeness and (forms of impoliteness) speakers of BE(LF) are to use/evaluate sociologically or to only recognise. For the teachers of BE(LF), this consequently means making decisions about the types of functional language they are to include in their course (e.g. various formulaic phrases referring to different levels of formality, for expressing indirectness, expressing rejections, expressing opinions, etc.). To illustrate, formulaic phrases used for expressing disagreement can vary from a simple and direct phrase ('I don't agree'), to something a bit more polite bit still direct ('Sorry, but I don't agree'), to quite indirect phrases, such as 'Well, that may be, but...' or 'I'm afraid that's not how I see it'.

The second concern is expressions of folk wisdom. Although one of the characteristics of BE(LF) is that it is clear, simple and without idiomatic expressions, its speakers may nevertheless use (in English) expressions of folk wisdom originating in their own culture. Let us consider idioms first. High-transparency idioms such as 'to bring something to the table', 'to compare apples to oranges' and 'to have one's hands tied' are more easily understood than low-transparency idioms such as 'to score 
brownie points', 'to bite the bullet', or 'to be an eager beaver'. In international business context, the low-transparency English idioms would most likely be the ones that would not be used by non-native English speakers, although they might be commonly used by native speakers of English. For example, idiomatic expressions such as 'to flog a dead horse', 'to get the wrong end of the stick', 'money for old rope', 'where there's muck, there's money' are not likely to be used in a dialogue between non-native speakers of English. They could, however, be used by native speakers of English.

Moreover, if for instance native speakers of English speak of 'the early bird catching the worm', the Slovenes speak of 'early hour, golden hour' and the Chinese say 'a fast foot is first to climb' (cf. Fordham 2010). When the Spanish talk about 'into a closed mouth flies will not enter', they mean 'think before you speak' and while they say 'there is no bad of which good does not come', the English speaking nations would say 'every cloud has a silver lining' (cf. Succeed at Spanish n. d.) and the Slovenes would say 'after every rain the sun starts to shine'. The question thus arises to what extent and which idioms, proverbs, etc. (if any) are to be taught in a Business English course. Are we to teach idiomatic expressions of English origin only, or should we look at other cultures as well? We believe that although non-native speakers of English may not necessarily actively use such expressions, it is advisable that they at least recognise their meaning.

\subsection{Intercultural awareness and intercultural competence}

Intercultural competence is closely related to sociolinguistic and sociocultural competence. According to Meyer $(1999,137)$

intercultural competence, as part of a broader foreign speaker competence, identifies the ability of a person to behave adequately and in a flexible manner when confronted with actions, attitudes and expectations of representatives of foreign cultures. Adequacy and flexibility imply an awareness of the cultural differences between one's own and foreign culture and the ability to handle cross-cultural problems which result from these differences.

Further, Byram (cited in Sercu 2005, 3) discusses the components of intercultural competence, which include, among other things, the knowledge of individual and societal interaction, the knowledge of how culture affects language and communication, the ability to interpret and relate, a positive disposition towards learning intercultural competence, and critical engagement with the foreign culture under consideration of one's own. As regards the users of English in an international business context, the importance of intercultural awareness and intercultural competence is (as we have seen above) undisputed.

How does this relate to the teaching of Business English and the teachers themselves? Since Business English practitioners are increasingly required to deliver language courses with an emphasis on crosscultural communication, they are faced with the challenge of addressing the issue of culture in their classrooms. Sercu $(2005,5)$ argues that "in order to support the intercultural learning process, foreign language teachers need additional knowledge, attitudes, competencies and skills to the ones hitherto thought of as necessary and sufficient for teaching communicative competence in a foreign language." Sercu further claims that "teachers need an adequate sociocultural knowledge of the target community, frequent and varied contacts with it and a thorough command of the pragmatic rules of use of the foreign language in contexts that may be considered to belong to their professional sphere" (Secru 2005, 5). Considering the global (multicultural) use of English for business-related purposes, this is quite a challenging (if not impossible) task. One could hardly be expected to acquire adequate knowledge of all target communities all over the world that will use English for Business Purposes. 
How can Business English practitioners therefore introduce intercultural topics into language courses? Frendo (2005) proposes two approaches. The first one is an "culture-general approach [which] encourages the learners to understand what culture is, gain awareness of how their own culture works, and appreciate that the way they do things is not necessarily the only way. [...] It is not about learning to deal with specific countries, but about how to deal with people who may have different ways of doing things" (Frendo 2005, 112-13). The second approach is "culture-specific training [if] the learners only need to deal with one or two cultures" (Frendo 2005, 113). According to Frendo (Frendo 2005, 113), this kind of approach can be superficial and may lead to excessive generalizations and stereotyping. Nevertheless, we would propose a combined culture-general and culture-specific approach to teaching intercultural contents on condition that the culture specific part does not become a mere list of dos and dont's. In our opinion, awareness-raising as regards different communication and behaviour patterns is the most important.

\section{Conclusion}

The aim of this paper was to discuss the concepts of cross-cultural communication in business related situations and to address some of the issues related to the teaching of English for Business Purposes in view of the increasing use of English in multicultural/international business and the consequent need to incorporate culture and cross-cultural related topics into Business English courses. Apart from presenting the international framework within which business people today operate, we have shown that the international business community strongly relies on the English language as the main tool for communication. Also, we have demonstrated that non-native speakers of English tend to transfer the patterns of their native languages and communication styles when speaking in English. We have also established that Business English as a lingua franca and as a neutral communication code is becoming an important variety of the English language, since it is perceived and used as a tool for communication between non-native speakers of English with other non-native speakers of English as well as with native speakers of English in business-related contexts.

The presentation of the current reality of the use of English for business purposes has also raised a number of questions concerning the contents of Business English courses. Our main concerns were the questions associated with the communicative, sociolinguistic and intercultural competences which should be developed within these courses.

Based on our discussion, we see the main role of Business English practitioners in teaching the language for effective communication in business-related context. In other words, the role of a business English teacher is to help the learners develop (enhance) their communicative language competence. This would enable them to successfully communicate in various business related situations, to achieve their business objectives and avoid mistakes. As regards Business English as a lingua franca, we agree with Kankaanranta (2008), who claims that "practitioners and trainers alike should approach intercultural business communication from a new perspective, the BELF one, which would make the specific aspects related to the use of English in intercultural business encounters explicit". In terms of the introduction of the incorporation of the topics on culture into Business English language courses, we believe that any such course should provide the students with, at least, a core understanding of how communication differs across cultures despite being carried out in the same language.

\section{References}

Council of Europe. 2001. Common European Framework of Reference for Languages: Learning, Teaching, Assessment. Cambridge: Cambridge University Press. 
Ehrenreich, Susanne. 2010. "English as a Business Lingua Franca in a German Multinational Corporation: Meeting the Challenge." Journal of Business Communication 47: 408-31.

Fordham, Carl Gene. 2010. "33 Proverbs that Translate Well Between English and Mandarin." The Yi bu yige jiaoyin Blog, December 14. Accessed August 20, 2012. http://carlgene.com/blog/2010/12/33-proverbs-thattranslate-well-between-english-and-mandarin/.

Frendo, Evan. 2005. How to Teach Business English. Harlow: Pearson Education Limited.

Gerritsen, Marinel, and Catherine Nickerson. 2009. "BELF: Business English as a Lingua Franca.” In The Handbook of Business Discourse. Edited by F. Bargiela Chiappini, 180-92. Edinburgh: Edinburgh University Press Ltd.

Graddol, David. 2006. English Next; Why global English may mean the end of 'English as a Foreign Lanugage'. London: British Council. http://www.britishcouncil.org/learning-research-english-next.pdf.

Gudykunst, William B., and Carmen M. Lee. 2003. "Cross-Cultural Communication Theories." In Cross-Cultural and Intercultural Communication, edited by William B. Gudykunst, 7-33. Thousand Oaks: Sage Publications, Inc.

Hall, Edward T., and Mildred Reed Hall. 1990. Understanding cultural differences. London: Nicholas Brealey International.

Holliday, Adrian, Martin Hyde, and John Kullman. 2010. Intercultural communication: An advanced resource book for students. London: Routledge.

IATEFL BESIG. 2012. "IATEFL BESIG Events.” Accessed August 17. http://www.besig.org/events/default.aspx.

Jung, Yeonkwon. 2009. "What Shall We Teach in English Business Communication Classes?: The Implications of Teaching Business in English vs. English in Business." The Journal of Intercultural Studies 36: 41-51.

Kankaanranta, Anne. 2008. "Business English Lingua Franca in Intercultural (Business) Communication.” Language at Work 3 (4). http://ojs.statsbiblioteket.dk/index.php/law/article/view/6193. Accessed August 20, 2012.

Kankaanranta, Anne, and Brigitte Planken. 2010. "Belf Competence as Business Knowledge of Internationally Operating Business Professionals.” Journal of Business Communication 47: 380-407.

Lewis, Richard D. 1999. Cross Cultural Communication - A Visual Approach. Warnford: Transcreen Publications. 2006. When Cultures Collide: Leading Across Cultures. London: Nicholas Brealey Publishing.

Louhiala-Salminen, Leena, and Anne Kankaanranta. 2012. "Language as an Issue In international Internal Communication: English or Local Language? If English, what English?” Public Relations Review 38 (2): 262-9.

Louhiala-Salminen, Leena, Mirjaliisa Charles, and Anne Kankaanranta. 2005. "English as a lingua franca in Nordic Corporate Mergers: Two Case Companies.” English for Specific Purposes 24: 401-21.

McKay, Sandra Lee. 2002. Teaching English as an International Language: Rethinking Goals and Approaches. Oxford: Oxford University Press.

Meyer, Meinert. 1999. "Developing Transcultural Competence: Case Studies of Advanced Language Learners." In Mediating Languages and Cultures: Towards an Intercultural Theory of Foreign Language Education, edited by Dieter Buttjes and Michael Byram, 136-158. Clevedon: Multilingual Matters, Ltd.

Pullin, Patricia. 2010. "Small Talk, Rapport, and International Communicative Competence: Lessons to Learn From BELF.” Journal of Business Communication 47: 455-76.

Randén, Petra. 2011. "Business English as a Lingua Franca-BELF in the Swedish Pharmaceutical Sector: A Study of the Needs of the Business English Speakers when Used as a Lingua Franca." BA thesis, Stockholm University, Faculty of Humanities, Department of English. http://su.diva-portal.org/smash/get/ diva2:549982/FULLTEXT01.pdf. Accessed August 20, 2012.

Rogerson-Revell, Pamela. 2010. “'Can You Spell That for Us Nonnative Speakers?' Accommodation Strategies in International Business Meetings.” Journal of Business Communication 47: 432-54. 
Seidlhofer, Barbara. 2005. “English as a Lingua Franca.” ELT Journal 59 (4): 339-41. http://eltj.oxfordjournals. org/content/59/4/339.full.pdf+html. Accessed August 20, 2012.

Sercu, Lies. 2005. “Teaching Foreign Languages in an Intercultural World.” In Foreign Language Teachers and Intercultural Competence: An International Investigation, edited by Lies Sercu, 1-18. Clevedon: Multilingual Matters.

Sharifian, Farzad. 2009. "English as an International Language: An Overview." In English as an International Language: Perspectives and pedagogical issues, edited by Farzad Sharifian, 1-20. Clevedon: Multilingual Matters.

Sharifian, Farzad, and Maryam Jamarani. 2013. Language and Intercultural Communication: From the Old Era to the New One. In Language and Intercultural Communication in the New Era, edited by Farzad Sharifian and Maryam Jamarani, 1-19. New York: Routlege.

Succeed at Spanish. n. d. "Learn Spanish Proverbs \& Sayings and Excel in Any Spanish Conversation!" Accessed August 18, 2012. http://www.succeed-at-spanish.com/spanish-proverbs.html.

Tannen, Deborah. 1984. "The pragmatics of cross-cultural communication." Applied Linguistics 5 (3): 189-95.

Wolfartsberger, Anita. 2009. "Managing Meetings in BELF (Business English as a Lingua Franca)." In Language for Professional Communication: Research, Practice and Training, edited by Vijay K. Bhatia, Winnie Cheng, Bertha Du-Babcock, and Jane Lung, 202-16. Hong Kong: City University of Hong Kong, AsiaPacific LSP and Professional Communication Association, The Hong Kong Polytechnic University. http://www.engl. polyu.edu.hk/rcpce/documents/LanguageForProfessionalCommunication.pdf. 